\title{
COVID-19 causing HELLP-like syndrome in pregnancy and role of angiogenic factors for differential diagnosis
}

\author{
Francesc Figueras ${ }^{1}$; Elisa Llurba ${ }^{2}$; Raigam Martinez-Portilla ${ }^{1}$; Josefina Mora ${ }^{3}$; Fatima Crispi ${ }^{1}$; \\ Eduard Gratacos ${ }^{1}$ \\ 1 Fetal i+D Fetal Medicine Research Center, BCNatal - Barcelona Center for Maternal-Fetal and \\ Neonatal Medicine (Hospital Clinic and Hospital Sant Joan de Deu), IDIBAPS, University of Barcelona, \\ and Center for Biomedical Research on Rare Diseases (CIBER-ER)
}

2 Servei de Ginecologia i Obstetricia. Hospital de la Santa Creu i Sant Pau

3 Servei de Bioquimica Clinica. Hospital de la Santa Creu i Sant Pau

\section{KEY-POINTS}

Question: Do pregnant women with symptomatic COVID-19 infection exhibit signs shared with preeclampsia and HELLP syndrome? Are these conditions ruled out by the measurement of angiogenic factors?

Findings: In series of 27 pregnancies with symptomatic COVID-19 infection, 7 presented at least one sign of suspected HELLP syndrome. In 6 of them, the level of angiogenic factors ruled out preeclampsia.

Meaning: Symptomatic COVID-19 may simulate severe pregnancy in pregnancy. Angiogenic factors may be essential to avoid false diagnosis and needless interventions.

These data were presented in a Virtual Symposium on Covid-19 and Pregnancy on 17 April:

2020:(http://medicinafetalbarcelona.org/simposiocovid19/ [Spanish]

and

https://medicinafetalbarcelona.org/symposiumcovid19/ [English]

\section{ABSTRACT}

Importance: The clinical presentation of hemolysis, elevated liver enzymes, and low platelet count (HELLP) syndrome is one of the more severe forms of preeclampsia. COVID-19 infection exhibits signs that are shared with preeclampsia and HELLP syndrome, which may lead to needless interventions and iatrogenic preterm delivery.

Objective: We evaluated the prevalence of HELLP-like signs in pregnant women admitted for COVID-19 and the value of angiogenic factors to rule out preeclampsia. 
medRxiv preprint doi: https://doi.org/10.1101/2020.07.10.20133801; this version posted July 11, 2020. The copyright holder for this preprint (which was not certified by peer review) is the author/funder, who has granted medRxiv a license to display the preprint in perpetuity.

All rights reserved. No reuse allowed without permission.

Methods: a consecutive series of 27 pregnant women beyond 20 weeks of gestation, with symptomatic COVID-19. Clinical and analytical features were recorded and those cases with signs of HELLP syndrome were tested for sFlt-1/PIGF ratio.

Results: Seven patients (25.9\%) presented at least one sign of suspected HELLP syndrome, of which 2 (7.4\%) were diagnosed clinically with PE because of hypertension and high transaminases and 5 (18.5\%) had only elevated transaminases. sFlt-1/PIGF ratio was normal in 6 of 7.

Conclusion: Symptomatic COVID-19 may simulate severe preeclampsia in pregnancy. Angiogenic factors may be essential to avoid false diagnosis and needless interventions.

\section{Introduction}

The COVID-19 outbreak has now rapidly spread worldwide, being declared by the WHO a pandemic infection on March $11^{\text {th }}$, with more than 1.2 million reported infections and 67,000 deaths (April $6^{\text {th }}$ ) (1). With more than 130,000 infections and 12,000 deaths, Spain is the second country in number of cases (1). The features of COVID-19 in pregnancy are still poorly described.

Symptomatic COVID-19 is characterized by flu-like symptoms, but in around $15 \%$ of cases it is developed a severe respiratory compromise or multi-organ failure (2). Abnormal aminotransferase and lactate dehydrogenase (LDH) levels and proteinuria are common features, not only in critically ill patients but also in milder forms of COVID-19 (3)(4). These signs could be clinically relevant in pregnant women. In pregnancy, the clinical presentation of hemolysis, elevated liver enzymes, and low platelet count (HELLP) syndrome is one of the more severe forms of preeclampsia because it has been associated with increased rates of maternal morbidity and mortality. HELLP syndrome may have an insidious and atypical onset, with up to $15 \%$ of the patients lacking either hypertension (5). Therefore, COVID-19 signs in pregnant women might lead to a misdiagnosis of preeclampsia and iatrogenic preterm delivery. Maternal levels of the angiogenic factors placental growth factor (PIGF), soluble fms-like tyrosine kinase, and particularly the ratio sFlt-1/PIGF have recently been proposed as highly specific markers in ruling out suspected preeclampsia (6).

There is no previous information on the frequency of preeclampsia-like signs in COVID-19 pregnant women and whether angiogenic factors might help in the differential diagnosis with true preeclampsia. In this series we recorded the clinical and analytical data of a consecutive series of 27 pregnant women with symptomatic COVID-19. We describe the prevalence of HELLP-like syndrome and the performance of sFIt-1/PIGF ratio to rule out true preeclampsia. 
medRxiv preprint doi: https://doi.org/10.1101/2020.07.10.20133801; this version posted July 11, 2020. The copyright holder for this preprint

(which was not certified by peer review) is the author/funder, who has granted medRxiv a license to display the preprint in perpetuity.

All rights reserved. No reuse allowed without permission.

\section{Methods}

A case-series was created of consecutive pregnant women of more than 20 weeks of gestation presenting with symptomatic COVID-19 between March $21^{\text {st }}$ and April $7^{\text {th }} 2020$, at two hospitals in Barcelona, with symptomatic and confirmed COVID-19 infection by quantitative RT-PCR on nasopharyngeal swabs.

This study was approved by the Ethics Committee of Hospital Sant Joan de Deu (PIC-56-20).

Symptomatic disease was defined by the presence acute respiratory tract infection (sudden onset of at least one of the following: cough, fever [central temperature $>38 \circ \mathrm{C}$ ], shortness of breath) with no other etiology that fully explains the clinical presentation

Management of patients followed the WHO guidance (7) .

In women in which there was a clinical suspicion of HELLP syndrome, maternal serum levels of soluble fms-like tyrosine kinase 1 [sFlt-1] and placental growth factor [PIGF] and sFlt1/PIGF ratio were determined by the fully automated Elecsys assays for sFlt-1 and PIGF on an electrochemiluminescence immunoassay platform (Cobas analyzers, Roche Diagnostics). Preeclampsia was defined according to ACOG criteria (5) and abnormal aminotransferase or lactate dehydrogenase levels were defined when above twice the upper laboratory reference value. 
medRxiv preprint doi: https://doi.org/10.1101/2020.07.10.20133801; this version posted July 11, 2020. The copyright holder for this preprint (which was not certified by peer review) is the author/funder, who has granted medRxiv a license to display the preprint in perpetuity.

All rights reserved. No reuse allowed without permission.

\section{Results}

A total of 27 pregnant women were included. Table 1 shows the baseline characteristics of the population. Overall, 7 patients (25.9\%) presented at least one sign of suspected HELLP syndrome, of which 2 (7.4\%) were diagnosed clinically with PE because of hypertension and proteinuria or elevated transaminases; $3(11.1 \%)$ had significant proteinuria plus elevated transaminases; and, 2 had isolated abnormal transaminase levels. sFlt-1/PIGF ratio was elevated over the cut-off for preeclampsia in 1 of 7 . Of note, magnesium sulphate was initiated in 2 patients, and discontinued in those with normal levels. There were no other obstetrical complications. Table 2 shows the clinical characteristics of these seven pregnancies. 
medRxiv preprint doi: https://doi.org/10.1101/2020.07.10.20133801; this version posted July 11, 2020. The copyright holder for this preprint

(which was not certified by peer review) is the author/funder, who has granted medRxiv a license to display the preprint in perpetuity.

All rights reserved. No reuse allowed without permission.

\section{Discussion}

The effect of COVID-19 infection on pregnancy is not well known because of the lack of reliable data. Small series from China suggest that the clinical characteristics of COVID-19 in pregnancy do not differ from those reported in non-pregnant adults $(8)(9)(10)$. In this series, rather than focusing on perinatal outcomes, we report that $26 \%$ of pregnant women presented clinical or analytical features currently considered for the diagnosis of preeclampsia or HELLP syndrome.

As already described in adults (3), we found abnormal aminotransferase or lactate dehydrogenase levels in one-third of cases. Massive proteinuria has also been reported in one-third of adults with COVID-19 (4). These signs are shared with preeclampsia, one of the most feared complications of pregnancy, which complicates $2 \%$ to $8 \%$ and is a leading cause of maternal morbidity and mortality (11) and iatrogenic prematurity (12). Accordingly, best practice guidelines for severe PE entails early treatment with magnesium sulphate and elective preterm delivery (5). Thus, obstetricians should be aware of the risk of misdiagnosing severe preeclampsia in COVID-19.

Other obstetric and medical disorders share clinical and laboratory findings with severe preeclampsia (13). Maternal levels of sFlt-1/PIGF, as markers of placental vasculogenesis, have a high performance in ruling out suspicion of preeclampsia (6). This preliminary series suggest that the performance of angiogenic factors is high in women with COVID-19 infection, and thus measuring angiogenic factors seems critical in COVID-19 pregnancies with PE-like analytical signs to rule out true PE, avoiding needless interventions and iatrogenic preterm delivery. 
medRxiv preprint doi: https://doi.org/10.1101/2020.07.10.20133801; this version posted July 11, 2020. The copyright holder for this preprint (which was not certified by peer review) is the author/funder, who has granted medRxiv a license to display the preprint in perpetuity. All rights reserved. No reuse allowed without permission.

Table 1. Baseline characteristics of the included population

\begin{tabular}{|c|c|}
\hline Maternal age (years) & $33(8) ; 20-45$ \\
\hline Gestational age at admission (weeks) & $33.6(8.2) ; 21.3-41.3$ \\
\hline \multicolumn{2}{|l|}{ Clinical symptoms } \\
\hline Cough & $20(74.1)$ \\
\hline Fever (>38우) & $15(55.6)$ \\
\hline Shortness of breath & $11(40.7)$ \\
\hline Diarrhea & $3(11.1)$ \\
\hline Respiratory rate (breaths/minute) & $22(9) ; 18-36$ \\
\hline Basal Oxygen Saturation (\%) & $97(5) ; 93-99$ \\
\hline Lymphocyte count (cells/ $\mu \mathrm{L}$ ) & 1267 (760); 750-2130 \\
\hline C-reactive protein $(\mathrm{mg} / \mathrm{dL})$ & $3.6(6.8) ; 0.1-26$ \\
\hline AST (U/L) & 45 (50); 14-706 \\
\hline $\operatorname{ALT}(\mathrm{U} / \mathrm{L})$ & $37(167): ; 11-363$ \\
\hline LDH (U/L) & $247(75) ; 174-985$ \\
\hline D-Dimer (ng/mL) & 2474(2039); 904-4310 \\
\hline Ongoing pregnancies & $16(59.3)$ \\
\hline Maternal complication & 0 \\
\hline \multicolumn{2}{|l|}{ Oxygen support } \\
\hline Nasal cannula-Venturi mask & $15(55.6)$ \\
\hline CPAP & $1(3.7)$ \\
\hline Intubation & 0 \\
\hline Hydroxichloroquine sulphate & $13(48.1)$ \\
\hline Azithromycin & $13(48.1)$ \\
\hline Cesarean section+ & $5(45.6)$ \\
\hline Birthweight (g)+ & $3300(574) ; 2566-3590$ \\
\hline Preterm birth $(<37$ weeks $)+$ & 0 \\
\hline SGA $\left(<10^{\text {th }}\right.$ centile $)$ & $1(3.7)$ \\
\hline Neonatal complication+ & 0 \\
\hline
\end{tabular}

Median (IQR) and range or $\mathrm{n}(\%)$, as appropriate

$+n=12$

IQR: Interquartile range; CPAP: Continuous Positive Airway Pressure; AST: Aspartate aminotransferase; ALT: Alanine aminotransferase; LDH: Lactate dehydrogenase; SGA: Smallfor-Gestational Age 
Table 2. Clinical characteristics of women with HELLP syndrome or preeclampsia suspicion

\begin{tabular}{|c|c|c|c|c|c|c|c|}
\hline & Case 1 & Case 2 & Case 3 & Case 4 & Case 5 & Case 6 & Case 7 \\
\hline Maternal age (years) & 33 & 24 & 29 & 36 & 32 & 43 & 26 \\
\hline Gestational age at admission (weeks) & $30^{+5}$ & $37^{+2}$ & $37^{+0}$ & $33^{+4}$ & $33+{ }^{6}$ & $21^{+3}$ & $33^{+0}$ \\
\hline Respiratory rate (breaths/minute) & 25 & 18 & 30 & 28 & 34 & 14 & 23 \\
\hline Basal Oxygen Saturation (\%) & 98 & 98 & 94 & 98 & 93 & 99 & 97 \\
\hline Lymphocyte count $\left(\times 10^{9} / \mathrm{L}\right)$ & 2 & 1.6 & 1.49 & 2.4 & 1.3 & 1.5 & 1.7 \\
\hline C-reactive protein (mg/dL) & NO & & 13.24 & 30 & 4.8 & 22 & 45 \\
\hline Platelet count $\left(\times 10^{9} / \mathrm{L}\right)$ & 341 & 189 & 167 & 182 & 126 & 315 & 201 \\
\hline Systolic blood pressure $(\mathrm{mmHg})$ & 153 & 146 & 117 & 113 & 115 & 123 & 100 \\
\hline Diastolic blood pressure $(\mathrm{mmHg})$ & 83 & 84 & 65 & 73 & 69 & 58 & 55 \\
\hline Proteinuria (mg/24h or dipstick) & 800 & - & 1178 & - & 602 & $1+$ & $2+$ \\
\hline AST (U/L) & 146 & 76 & 706 & 156 & 175 & 177 & 77 \\
\hline $\operatorname{ALT}(\mathrm{U} / \mathrm{L})$ & 268 & 46 & 271 & 190 & 363 & 118 & 81 \\
\hline $\mathrm{LDH}(\mathrm{U} / \mathrm{L})$ & 227 & 360 & 985 & 301 & 282 & 345 & 243 \\
\hline D-Dimer (mg/mL) & - & 2450 & 2300 & 1561 & 4020 & - & - \\
\hline PIGF (pg/mL) & 506 & 257 & 77 & 141 & 206 & 302 & 625 \\
\hline sFlt-1 (pg/mL) & 1385 & 21689 & 32375 & 9273 & 5119 & 3207 & 3098 \\
\hline sFlt-1/PIGF ratio & 3 & 84 & 423 & 66 & 25 & 11 & 5 \\
\hline Maternal complication & No & No & No & No & No & No & No \\
\hline Gestational age at delivery & - & $37+2$ & $37+0$ & - & - & - & - \\
\hline Birthweight & - & 2898 & 3300 & - & - & - & - \\
\hline Neonatal RT-PCR & - & Negative & Negative & - & - & - & - \\
\hline Neonatal complication & - & No & No & - & - & - & - \\
\hline
\end{tabular}

AST: Aspartate aminotransferase; ALT: Alanine aminotransferase; LDH: Lactate dehydrogenase; PLGF: placental growth factor;

sFlt-1: Soluble fms-like tyrosine kinase-1; RT-PCR: Real-Time Polymerase Chain Reaction 
medRxiv preprint doi: https://doi.org/10.1101/2020.07.10.20133801; this version posted July 11, 2020. The copyright holder for this preprint (which was not certified by peer review) is the author/funder, who has granted medRxiv a license to display the preprint in perpetuity.

\section{References}

1. WHO. Situation Report-77 HIGHLIGHTS.

2. Zhou F, Yu T, Du R, Fan G, Liu Y, Liu Z, et al. Clinical course and risk factors for mortality of adult inpatients with COVID-19 in Wuhan, China: a retrospective cohort study. Lancet. 2020 Mar 28;395(10229):1054-62.

3. Bangash MN, Patel J, Parekh D. COVID-19 and the liver: little cause for concern. Lancet Gastroenterol Hepatol. 2020 Mar;0(0).

4. $\quad$ Li Z, Wu M, Guo J, Yao J, Liao X, Song S, et al. Caution on Kidney Dysfunctions of 2019nCoV Patients. medRxiv. 2020 Mar 27;2020.02.08.20021212.

5. ACOG Practice Bulletin No. 202: Gestational Hypertension and Preeclampsia. Obstet Gynecol. 2019 Jan 1;133(1):e1-25.

6. Zeisler H, Llurba E, Chantraine F, Vatish M, Staff AC, Sennström M, et al. Predictive Value of the sFlt-1:PIGF Ratio in Women with Suspected Preeclampsia. N Engl J Med. 2016;374(1):13-22.

7. World Health Organization (WHO). Clinical management of severe acute respiratory infection (SARI) when COVID-19 disease is suspectede) [Internet]. 2020 [cited $2020 \mathrm{Apr}$ 8]. Available from: https://www.who.int/publications-detail/home-care-for-patientswith-suspected-novel-coronavirus-

8. Zeng L, Xia S, Yuan W, Yan K, Xiao F, Shao J, et al. Neonatal Early-Onset Infection With SARS-CoV-2 in 33 Neonates Born to Mothers With COVID-19 in Wuhan, China. JAMA Pediatr [Internet]. 2020 Mar 26 [cited 2020 Apr 5]; Available from: https://jamanetwork.com/journals/jamapediatrics/fullarticle/2763787

9. Liu D, Li L, Wu X, Zheng D, Wang J, Yang L, et al. Pregnancy and Perinatal Outcomes of Women With Coronavirus Disease (COVID-19) Pneumonia: A Preliminary Analysis. Am J Roentgenol [Internet]. 2020 Mar 18 [cited 2020 Apr 5];1-6. Available from: https://www.ajronline.org/doi/10.2214/AJR.20.23072

10. Zhang L, Jiang Y, Wei M, Cheng BH, Zhou XC, Li J, et al. [Analysis of the pregnancy outcomes in pregnant women with COVID-19 in Hubei Province]. Zhonghua Fu Chan Ke Za Zhi [Internet]. 2020 Mar 7 [cited 2020 Apr 5];55(0):E009. Available from: http://www.ncbi.nlm.nih.gov/pubmed/32145714

11. Steegers EA, von Dadelszen P, Duvekot JJ, Pijnenborg R. Pre-eclampsia. Lancet. 2010;376(9741):631-44.

12. lams JD, Goldenberg RL, Mercer BM, Moawad A, Thom E, Meis PJ, et al. The Preterm Prediction Study: recurrence risk of spontaneous preterm birth. National Institute of Child Health and Human Development Maternal-Fetal Medicine Units Network. Am J 
medRxiv preprint doi: https://doi.org/10.1101/2020.07.10.20133801; this version posted July 11, 2020. The copyright holder for this preprint (which was not certified by peer review) is the author/funder, who has granted medRxiv a license to display the preprint in perpetuity.

All rights reserved. No reuse allowed without permission.

Obstet Gynecol. 1998;178(5):1035-40.

13. Sibai BM. Imitators of severe preeclampsia. Vol. 109, Obstetrics and Gynecology. Obstet Gynecol; 2007. p. 956-66. 